\title{
The Effectiveness Of Pre-Planting Seeds Bio-Matriconditioning And Application Of Fertilization With Leisa Technique On Growth Of Areca Nut Seedling (Areca Catechu L.)
}

\author{
Gusti Ayu Kade Sutariati ${ }^{*}$, Muhidin ${ }^{2}$, Nini Mila Rahni ${ }^{3}$, Gusti Ngurah Adi Wibawa ${ }^{4}$, La Mudi ${ }^{5}$ \\ ${ }^{1,2,3}$ Department of Agrotechnology, Faculty of Agriculture, University of Halu Oleo, \\ Kendari Southeast Sulawesi 93232 Indonesia \\ ${ }^{4}$ Department of Statistics, Math and Science Faculty, University of Halu Oleo, \\ Kendari Southeast Sulawesi 93232 Indonesia \\ ${ }^{5}$ Department of Plantation Crop Cultivation, State Agricultural Polytechnic of Samarinda, 7513, \\ Indonesia \\ *Corresponding author: \\ Email: sutariati69@yahoo.co.id
}

\begin{abstract}
.
Areca nut is widely used as industrial raw material, both for health and cosmetics and as a source of renewable energy. This study aimed to examine the combination of seed bombatriconditioning and LEISA fertilization treatments that were effective in increasing the growth of areca nut seedlings. The research was carried out in the Wua-Wua Kendari Village, from March to July 2021. The study used a split-plot design with a completely randomized design (CRD). The main plot is seed biomatriconditioning treatment which consists of 3 treatments. While the subplots were fertilized with the LEISA technique which consisted of 6 treatments so that 18 treatment combinations were obtained with 3 replications. Observations were made on plant height, number of leaves, stem diameter, number of roots, wet weight and dry weight of shoot. Observational data were analyzed using analysis of variance, followed by the DMRT $\alpha_{0.05}$ if there was a significant effect. The results showed that seed biomatriconditioning treatment with rhizobacteria integrated with the LEISA technique was able to increase the growth of areca nut seedlings. The integration between L1R biomatriconditioning and the application of organic plus fertilizer $+100 \%$ inorganic fertilizer showed a better growth performance of areca nut on plant height, number of leaves, stem diameter, number of roots, wet weight and dry weight of betel nut which were significantly different with control and application 100\% inorganic fertilizer, but not significantly different from organic plus fertilizer, organic plus fertilizer $+50 \%$ inorganic fertilizer and organic plus fertilizer $+25 \%$ inorganic fertilizer. As a conclusion, pre-planting seed treatment with L1R biomatriconditioning is very important to increase areca nut seed germination. To increase the growth of areca nut seedlings, further fertilization needs to be done with organic plus fertilizer or a combination of organic plus fertilizer $+25 \%$ inorganic fertilizer.
\end{abstract}

Keywords: Areca nut; biomatricondtioning; inorganic fertilizer; LEISA; organic plus; seedling

\section{INTRODUCTION}

Areca nut is one of the most widely used palm plants as industrial raw materials, both for health and cosmetics. However, the areca nut cultivation system is limited by cultivation techniques, especially seeds that are in the latent phase. Areca nut contains arecoline, an alkaloid that is beneficial for health ${ }^{1}$. Areca nut is also reported to contain high phenolic and flavonoid compounds ${ }^{2}$ and also contains cellulose, hemicellulose and lignin ${ }^{3}$. In addition, areca nut can also be used as a source of renewable energy ${ }^{4}$. However, in reality, areca nut has not been widely developed by the community even though this plant provides many benefits and has the opportunity as an export crop. Southeast Sulawesi has a large dry land and very potential for the development of areca nut.The main obstacle to the development of areca nut in Southeast Sulawesi is the use of poor quality seeds that affect plant growth in the field. In addition, other factors that affect plant growth and yield are application of fertilizers for plant nutrient needs. Therefore, in order to overcome these problems, technological inputs are needed that can overcome the problem of quality seeds and fulfill sufficient nutrient needs for plant growth. Technological input that can be done is by using the biomatriconditioning technique of pre-planting seeds. Seed biomatricondtioning was reported to be able to increase plant growth and yield ${ }^{5,6,7}$. In addition to pre-planting seed treatment, additional treatment inputs are also required by integrating the use of organic plus and inorganic fertilizers to meet crop needs through an integrated approach to sustainable agriculture in the form of Low External Input Sustainable Agriculture (LEISA). 
The LEISA fertilization technique refers to a form of agriculture that aims to optimize the use of existing local resources ${ }^{8,9,10}$. The LEISA fertilization technique is not intended to maximize production in the short term, but rather to achieve stable and adequate production levels in the long term. The integration of the use of microbes with the LEISA technique is able to support food security and the sustainability of agricultural systems11. It was further reported that the use of the LEISA technique was able to improve the physical, chemical and biological properties of the soil, improve crop quality and production12. Another study reported that the combination of organic fertilizers with the addition of inorganic fertilizers was able to increase crop yields ${ }^{13,14,15}$. The use of organic plus fertilizers is reported to be able to increase plant growth and yields. This is because organic plus fertilizer contains nutrients needed by plants and also contains biological agents that can increase plant growth. The biological agents contained in organic plus fertilizers play a role in synthesizing growth hormones in the form of IAA, dissolving phosphate and fixing nitrogen and can act as biological control agents ${ }^{16,17,18,19}$.

Meanwhile, the addition of inorganic fertilizers is expected to be able to provide plant nutrients in a fast time according to the dose needed by plants. Thus, this combination is expected to be able to provide a significant effect in increasing the growth of areca nut which in turn has an impact on increasing crop yields. Based on these advantages, the integration of biomatriconditioning and LEISA techniques is also expected to increase the growth of areca nut. This study aims to test the combination of seed biomatriconditioning treatment and LEISA technique fertilization which is effective in increasing the growth of areca nut seedlings.otato cultivation experiment was carried out using five different doses of chicken manure compost, organic compost, and chemical fertilizers, which contained nitrogen, phosphate, and potassium. Chemical fertilizer was applied at $250 \mathrm{~kg} / \mathrm{ha}$, while the compost doses were 10, 12.5, 15, 17.5, and 20 tons/ha. The microbial Minerals decomposed the compost into macro and micronutrients, which improved the soil cation exchange capacity between $24 \pm 0.8-27.6 \pm 1.2 \mathrm{meg} / 100 \mathrm{~g}$. The results showed improved physical and chemical properties of the soil, increasing the productivity and quality of potatoes produced.

\section{METHODS}

The research was carried out in Wua-Wua Kendari Village, from March to July 2021. The study used a split-plot design with the basic design of a completely randomized design (CRD). Main plot is seed biomatriconditioning technique which consists of 3 treatments, namely control, biomatricontinioning L1R and biomatriconditioning LA2E. Meanwhile, the sub-plots were using the LEISA technique which consisted of 6 treatments, namely control (without application of organic plus and inorganic fertilizers) (G0), organic plus fertilizer (G1), 100\% inorganic fertilizer (G2), organic plus + inorganic fertilizer 100\% (G3), organic plus fertilizer $+50 \%$ inorganic fertilizer (G4) and organic plus fertilizer $+25 \%$ inorganic fertilizer (G5). Each treatment was repeated 3 times so that there were 54 experimental units in total.

The planting media used in this study were Ultisol soil and rice husk charcoal. The two media were mixed and then filtered through a $0.5 \mathrm{~cm}$ diameter sieve. Then the planting medium was put into a polybag measuring $25 \mathrm{~cm} \times 25 \mathrm{~cm}$. The areca nut seeds used in this study had been previously applied with the seed biomatricontioning treatment ${ }^{20}$ and have germinated. Seedlings were selected of uniform size with a height of $\pm 5 \mathrm{~cm}$. Furthermore, the areca nut seedlings were planted in polybags that had been previously provided as many as 1 seed per polybag according to the treatment. The application of the LEISA technique is carried out 2 weeks after transplanting. The observed variables were plant height, number of leaves, stem diameter, number of roots, wet weight and dry weight of wilted. Observational data were analyzed using analysis of variance. The results of the analysis that showed a significant effect were continued with the Duncan Multiple Range Test (DMRT) $\alpha=0.05$.

\section{RESULT AND DISCUSSION Seedling height}

There was an interaction between the seed biomatriconditioning treatment and the LEISA technique on the height of areca nut seedlings aged $8 \mathrm{WAP}$. The interaction of the L1R biomatriconditioing treatment with the application of organic plus fertilizers and 100\% inorganic fertilizers, showed better plant high 
performance compared to other treatments, but was not significantly different from the organic plus fertilizer treatment. Meanwhile, L1R or LA2E biomatriconditioning gave the same effect, but significantly different from the control (Table 1).

Table 1.The interaction of seed biomatriconditioning treatment and LEISA technique on the height of areca nut seedlings aged 8 WAP

\begin{tabular}{lcccccc}
\hline Biomatriconditioning & \multicolumn{7}{c}{ LEISA technique } \\
\cline { 2 - 7 } treatments & $\mathrm{G} 0$ & $\mathrm{G} 1$ & $\mathrm{G} 2$ & $\mathrm{G} 3$ & $\mathrm{G} 4$ & $\mathrm{G} 5$ \\
\hline Control & $13.50 \mathrm{~b}$ & $18.67 \mathrm{c}$ & $15.33 \mathrm{c}$ & $19.67 \mathrm{c}$ & $18.17 \mathrm{~b}$ & $17.83 \mathrm{~b}$ \\
& $\mathrm{R}$ & $\mathrm{PQ}$ & $\mathrm{QR}$ & $\mathrm{P}$ & $\mathrm{Q}$ & $\mathrm{Q}$ \\
Biomatric. L1R & $17.67 \mathrm{a}$ & $33.50 \mathrm{a}$ & $23.00 \mathrm{a}$ & $35.00 \mathrm{a}$ & $32.17 \mathrm{a}$ & $31.00 \mathrm{a}$ \\
& $\mathrm{R}$ & $\mathrm{PQ}$ & $\mathrm{R}$ & $\mathrm{P}$ & $\mathrm{Q}$ & $\mathrm{Q}$ \\
Biomatric. LA2E & $18.67 \mathrm{a}$ & $32.67 \mathrm{~b}$ & $21.00 \mathrm{~b}$ & $32.33 \mathrm{~b}$ & $31.17 \mathrm{a}$ & $31.00 \mathrm{a}$ \\
& $\mathrm{S}$ & $\mathrm{P}$ & $\mathrm{R}$ & $\mathrm{P}$ & $\mathrm{Q}$ & $\mathrm{Q}$ \\
\hline
\end{tabular}

Note: The numbers followed by the same lowercase letter (a-b) in the same column, and the numbers followed by the same capital letter (P-R) in the same row show no significant difference at the DMRT $\alpha_{0.05}$

\section{Number of leaves}

There was an interaction between the seed biomatriconditioning treatment and the LEISA technique on the number of leaves of areca nut seedlings aged 8 WAP. Except for the control (either the biomatriconditioning treatment or the LEISA technique), all treatments showed the same performance in producing leaf count at $8 \mathrm{WAP}$. The application of organic plus fertilizer, either alone or in combination with inorganic fertilizers, gave the same number of leaves. Only application of $100 \%$ inorganic fertilizer gave lower number of leaves, but statistically it was not significantly different from other treatments, except control (Table 2).

Table 2. Interaction of seed biomatriconditioning treatment and LEISA technique on the number of leaves of areca nut seedlings aged 8 WAP

\begin{tabular}{|c|c|c|c|c|c|c|c|c|c|c|c|c|}
\hline \multirow{2}{*}{$\begin{array}{c}\text { Biomatriconditioning } \\
\text { treatments }\end{array}$} & \multicolumn{12}{|c|}{ LEISA technique } \\
\hline & G0 & & G1 & & G2 & & G3 & & G4 & & G5 & \\
\hline Control & $\begin{array}{r}1,00 \\
P\end{array}$ & $\mathrm{~b}$ & $\begin{array}{r}1,00 \\
P\end{array}$ & $\mathrm{~b}$ & $\begin{array}{r}1,00 \\
P\end{array}$ & $\mathrm{~b}$ & $\begin{array}{r}1,00 \\
P\end{array}$ & $\mathrm{~b}$ & $\begin{array}{r}1,00 \\
P\end{array}$ & $\mathrm{~b}$ & $\begin{array}{r}1,00 \\
P\end{array}$ & $\mathrm{~b}$ \\
\hline Biomatric. L1R & $\begin{array}{r}1,00 \\
\mathrm{Q}\end{array}$ & b & $\begin{array}{r}2,00 \\
P\end{array}$ & $\mathrm{a}$ & $\begin{array}{r}1,83 \\
P Q\end{array}$ & $\mathrm{a}$ & $\begin{array}{r}2,00 \\
P\end{array}$ & $\mathrm{a}$ & $\begin{array}{r}2,00 \\
P\end{array}$ & $\mathrm{a}$ & $\begin{array}{r}2,00 \\
P\end{array}$ & $\mathrm{a}$ \\
\hline Biomatric. LA2E & $\begin{array}{r}1,67 \\
\mathrm{Q}\end{array}$ & $\mathrm{a}$ & $\begin{array}{r}2,00 \\
P\end{array}$ & $\mathrm{a}$ & $\begin{array}{r}1,83 \\
\mathrm{PQ}\end{array}$ & $\mathrm{a}$ & $\begin{array}{r}2,00 \\
P\end{array}$ & $\mathrm{a}$ & $\begin{array}{r}2,00 \\
P\end{array}$ & $\mathrm{a}$ & $\begin{array}{r}2,00 \\
P\end{array}$ & $\mathrm{a}$ \\
\hline
\end{tabular}

Note: The numbers followed by the same lowercase letter (a-b) in the same column, and the numbers followed by the same capital letter (P-R) in the same row show no significant difference at the DMRT $\alpha_{0.05}$

\section{Stem diameter}

There was no interaction between seed biomatriconditioning treatment and LEISA technique on stem diameter of areca nut seedlings. Independently, the biomatriconditioning treatment significantly increased the diameter of the areca nut seedlings compared to the control. Biomatriconditioning L1R was better able to increase stem diameter of areca nut which was significantly different from control and isolate LA2E. Independently, the LEISA technique, which combines the use of organic and inorganic fertilizers, significantly increased the stem diameter of areca nut seeds compared to the control. The application of organic plus fertilizers either independently or in combination with inorganic fertilizers gave significantly different stem diameters with control and application of $100 \%$ inorganic fertilizers (Table 3).

\section{Number of roots}

There was no interaction between the biomatriconditioning treatment and the LEISA technique on the number of roots of areca nut seedlings. Independently, the seed biomatriconditioning treatment significantly increased the number of roots of areca nut seedlings compared to the control. Biomatriconditioning L1R and LA2E produced a higher number of roots and was significantly different from the control. Independently, the LEISA technique significantly increased the number of roots of areca nut seedlings compared to the control. The application of organic plus fertilizer combined with $100 \%$ inorganic fertilizer gave a higher number of roots, not significantly different from other combination treatments, but significantly different from the control and application of $100 \%$ inorganic fertilizer (Table 3). 
Table 3. Effect of seed biomatriconditioning treatment and LEISA technique on stem diameter (SD), number of roots (NR), wet weight of shoot (WWS) and dry weight of shoot (DWS)

\begin{tabular}{lrrrr}
\hline \multicolumn{1}{c}{ Biomatriconditioning treatments } & \multicolumn{4}{c}{ Observation variable } \\
\cline { 2 - 5 } & SD & \multicolumn{1}{c}{ NR } & WWS & DWS \\
\hline Control & $59.27 \mathrm{c}$ & $9.67 \mathrm{~b}$ & $10.17 \mathrm{~b}$ & $4.14 \mathrm{c}$ \\
Biomatric-L1R & $72.32 \mathrm{a}$ & $16.67 \mathrm{a}$ & $17.32 \mathrm{a}$ & $8.73 \mathrm{a}$ \\
Biomatric-LA2E & $67.67 \mathrm{~b}$ & $15.72 \mathrm{a}$ & $16.16 \mathrm{a}$ & $7.33 \mathrm{~b}$ \\
\hline \multicolumn{1}{c}{ LEISA technique } & & & & \\
\hline Control & $49.33 \mathrm{c}$ & $7.78 \mathrm{~d}$ & $9.81 \mathrm{c}$ & $3.12 \mathrm{c}$ \\
Organic plus fertilizer & $71.56 \mathrm{a}$ & $16.56 \mathrm{ab}$ & $16.82 \mathrm{a}$ & $8.95 \mathrm{a}$ \\
100\% inorganic fertilizer & $57.75 \mathrm{~b}$ & $10.11 \mathrm{c}$ & $11.91 \mathrm{~b}$ & $4.63 \mathrm{c}$ \\
Organic plus fertilizer $+100 \%$ inorganic fertilizer & $76.77 \mathrm{a}$ & $17.11 \mathrm{a}$ & $17.54 \mathrm{a}$ & $8.85 \mathrm{a}$ \\
Organic plus fertilizer $+50 \%$ inorganic fertilizer & $70.87 \mathrm{a}$ & $16.22 \mathrm{ab}$ & $15.53 \mathrm{a}$ & $7.60 \mathrm{ab}$ \\
Organic plus fertilizer $+25 \%$ inorganic fertilizer & $71.35 \mathrm{a}$ & $16.33 \mathrm{ab}$ & $15.70 \mathrm{a}$ & $7.75 \mathrm{ab}$ \\
\hline
\end{tabular}

Note: The numbers followed by the same letter in the column for each variable show no significant difference in the DMRT $\alpha_{0.05}$

\section{Wet weight and dry weight of shoot}

There was no interaction between biomatriconditioning treatment and LEISA technique on shoot wet weight and dry weight of areca nut seedlings. Independently, the biomatriconditioning treatment significantly increased the shoot wet weight and dry weight of areca nut seedlings compared to the control. Biomatriconditioning L1R was better able to increase shoot wet and dry weight of areca nut seedlings, which was significantly different from control and isolate LA2E. Independently, the LEISA technique treatment significantly increased the shoot wet weight and dry weight of areca nut seedlings compared to the control. Application of organic plus fertilizer combined with $100 \%$ inorganic fertilizer resulted in better shoot wet weight and dry weight, not significantly different from other combination treatments, but significantly different from control and application of 100\% inorganic fertilizer (Table 3). The growth performance of areca nut in the L1R biomatriconditioning treatment and the LEISA technique is shown in Figure 1.

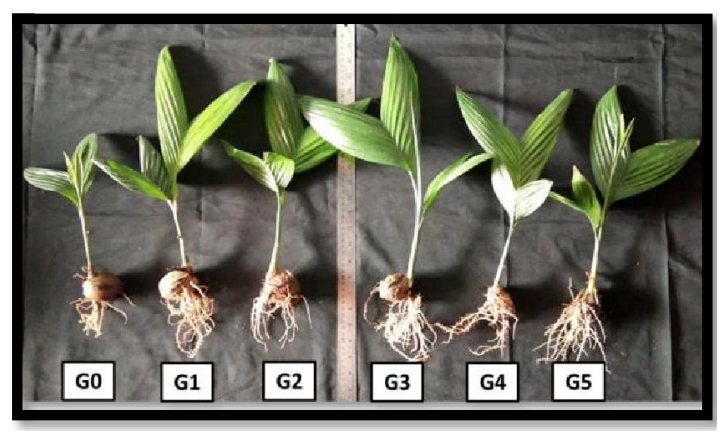

Fig 1.Growth performance of areca nut seedlings on L1R biomatriconditioning treatment and LEISA technique

Seed biomatriconditioning treatment which was integrated with biological agents was significantly able to increase the growth of areca nut seedlings. The results of this study are also in line with the results of previous studies which showed that the use of biological agents as seed treatment was able to improve and increase plant growth and yield. Endophytic-rhizobacteria inoculation which was integrated with the matriconditioning technique of husk charcoal powder gave better results than the control. As previously explained, Bacillus spp. is a group of PGPR (Plant Growth Promoting Rhizobacteria) that are effective in increasing plant growth and yield. The role of these endophytic-rhizobacteria as PGPR is because these bacteria have the ability to dissolve phosphate, fix nitrogen, and produce growth hormones such as IAA and cytokinins $^{21}$. The results of previous studies that are relevant to this study indicate that the use of biological agents can increase seed germination ${ }^{22,23,24,25}$.In addition to the improvements caused by the use of endophytic-rhizobacteria independently, the application of biomatriconditioning techniques as a medium for inoculation of rhizobacteria in seeds also provides a positive role that cannot be ignored. As previously explained, the seed biomatriconditioning technique is a treatment on seeds (seed conditioning) which aims to accelerate and uniform growth and increase the percentage of sprouts and seedlings appearing. The principle 
is to mobilize resources owned by seeds (internal) plus external resources (external) to maximize the improvement of plant growth and yields.

Seed conditioning is a physiological and biochemical improvement associated with the speed and simultaneousness, improvement and increase in germination potential in seeds during delayed germination by low matrix potential media (matriconditioning) or by low osmotic potential media (priming or osmoconditioning). The use of seed matriconditioning techniques has been shown to be effective in increasing seed viability and vigor ${ }^{26}$ and protecting planted seeds from seed-borne and soil-borne fungi ${ }^{27,28,29}$. Meanwhile, as previously explained, the seed biomatriconditioning technique through seed conditioning treatment is indeed used to accelerate and uniform growth and increase the percentage of sprouts and seedlings appearing ${ }^{30}$. The principle of seed conditioning is to mobilize the resources owned by the seed (internal) plus external resources to maximize the improvement of plant growth and yield. Seed conditioning is a physiological and biochemical improvement associated with the speed and simultaneous, increased germination potential in seeds during delayed germination by low matrix potential media (matriconditioning) or by low osmotic potential media (osmoconditioning) ${ }^{31}$. Seed matriconditioning technique proved to be effective in increasing seed viability and vigor ${ }^{26,30}$. In addition to promoting early seed growth, this technology has also been shown to be able to protect seeds from seed-borne and soil-borne fungi during an important early stage of growth ${ }^{32,33}$.Seed biomatriconditioning treatment with rhizobacteria integrated with the LEISA technique was also able to increase the growth of areca nut seedlings.

The integration between the biomatriconditioning technique using L1R and the application of organic fertilizer plus $+100 \%$ inorganic fertilizer showed a better growth performance of areca nut and significantly different from the control and application of $100 \%$ inorganic fertilizer, but not significantly different from the application of organic fertilizer plus, application of organic plus fertilizer. $+50 \%$ inorganic fertilizer and application organic plus fertilizer $+25 \%$ inorganic fertilizer. This is in line with the results of previous studies that endophytic-rhizobacteria present in the plant rhizosphere have an important role in improving plant growth and yield ${ }^{6,7}$. The increase in the growth of areca nut is also due to the input of inorganic and organic fertilizers in the form of organic plus fertilizers containing biological agents. The use of inorganic and organic fertilizers is reported to be able to improve the physical, chemical and biological properties of the soil ${ }^{12}$. In addition, the use of organic plus fertilizers also plays a role in supplying nitrogen and phosphate needs because the biological agents contained in organic plus fertilizers have the ability to dissolve phosphate, fix nitrogen and produce growth hormones ${ }^{34,35,36}$. It was further reported that biological agents can chelate important elements from the area around plant roots so that they can be utilized by plants $^{37}$. Bacillus spp., and P. fluorescens are also capable of synthesizing growth hormones, fixing nitrogen or dissolving phosphate $38,39,40,41$. As previously explained, Bacillus spp. is a group of PGPR bacteria that is proven to be effective in increasing plant growth and yield ${ }^{42,43,44}$. Bacillus spp. reported to be able to synthesize indole acetic acid (IAA) ${ }^{46}$, gibberellins ${ }^{47}$ and dissolve phosphate ${ }^{44,49,50}$.

Previous research showed that rhizobacteria isolates from the Bacillus sp. able to produce growth hormone IAA $^{51}$. Furthermore, it was reported that rhizobacteria from the Bacillus sp. capable of producing the hormone IAA and dissolving phosphate41. Besides being able to produce IAA hormone and dissolve phosphate, rhizobacteria from the Bacillus sp. also able to fix nitrogen ${ }^{52,53,54}$. The IAA hormone produced by rhizobacteria is thought to be able to stimulate seed germination, resulting in accelerated seed germination. The application of gibberellins can increase the percentage of seed germination by increasing the amino acids contained in the embryo and this is important to maximize hydrolytic enzymes in the endosperm when new seeds germinate ${ }^{55}$. As with rhizobacteria, the use of endophytic bacteria as plant growth promoters is also one of the contributions of biotechnology in increasing plant growth and production. This group of endophytic bacteria from the roots of areca nut is proven to be able to produce the hormone IAA, so the presence of endophytic bacteria in plants can increase the growth of areca nut seedlings ${ }^{37}$. IAA hormone is a type of auxin, involved in physiological processes in plant growth such as cell elongation and division, tissue differentiation and root initiation. ${ }^{56,57}$. 


\section{CONCLUSION}

Pre-planting seed treatment with L1R biomatriconditioning is very important to increase areca nut seed germination. To increase the growth of areca nut seedlings, further fertilization needs to be done with organic plus fertilizer or a combination of organic plus fertilizer $+25 \%$ inorganic fertilizer.

\section{ACKNOWLEDGEMENT}

We would like to thank the Ministry of Research and Technology / BRIN for funding this research, through the 2021 Basic Research grant. The authors gratefully acknowledge for financial support from the Ministry of Research and Technology/BRIN of Indonesia under Penelitian Dasar No. 026/E4.1/AK.04.PT/2021.

\section{REFERENCES}

[1] Cox, S. M. Ullah and H. Zoellner, 2016. Oral and systemic health effects of compulsive areca nut use neuropathology of drug addictions and substance misuse. Academic Press. 2016, pp. 785-793. https://doi.org/10.1016/B978-0-12-800634-4.00078-0.

[2] Sari, L.M., G. Permana and E. Ibrahim, 2017. Potential antioxidant and cytotoxic activities of areca nut (Areca catechu Linn.) extract in human oral squamous cell carcinoma and keratinocyte cells. Asian Journal of Pharmaceutical and Clinical Research, 10: 286-291. https://doi.org/10.22159/ajpcr.2017.v10i10.20287.

[3] Lazim, Y., S.M. Salit, E.S. Zainudin, M. Mustapha and M. Jawaid, 2014. Effect of alkali treatment on the physical, mechanical, and morphological properties of waste betel nut (Areca catechu) husk fibre. BioResources. 9: 7721-7736. https://doi.org/10.15376/biores.9.4.7721-7736.

[4] Setyawan, H.Y., Sunaryo, B. Waluyo, Merlya, A. Choirun, A. Nizori, and Sahrial, 2020. Energy potential from areca palm through direct combustion and pyrolysis in Indonesia: a review. Indonesian Food Science and Technology Journal. 4: 19-26.

[5] Sutariati, G.A.K., A. Khaeruni, Y.B. Pasolon and L. Mudi. 2016. The effect of seed bio-invigoration using indigenous rhizobacteria to improve viability and vigor of upland rice (oryza sativa L.) Seeds. International Journal of PharmTech Research, 9: 565-573.

[6] Sutariati, G.A.K., Muhidin, T.C. Rakian, L.O. AFa, I. Wiadanta, L. Mudi, G.R. adimantara and S. Leomo, 2018. The effect of integrated application of pre-plant seed bio-invigoration, organic and inorganic fertilizer on the growth and yield of local upland rice. Bioscience Research, 15: 160-165.

[7] Wangadi, S., G.A.K. Sutariati dan A. Khaeruni, 2018. Kajian teknik bio-invigorasi benih dan LEISA untuk meningkatkan pertumbuhan padi gogo lokal pada skala rumah kasa. J. Berkala Penelitian Agronomi 6: 1-10.

[8] Nuraini, A., Y. Yuwariah dan Y. Rochayat, 2015. Pengembangan produksi pertanian lahan kering dengan sistem low external input sustainable agriculture (LEISA) di Desa Cigadog, dan Mandalagiri Kecamatan, Leuwisari Kabupaten Tasikmalaya. Dharmakarya: Jurnal Aplikasi Ipteks untuk Masyarakat, 4: 113 - 118.

[9] Oberč, B.P. \& A.A. Schnell, 2020. Approaches to sustainable agriculture. Exploring the pathways towards the future of farming. Brussels, Belgium: IUCN EURO.

[10] Sridhar, S.M. \& C.P. Swaminathan, 2020. Low External Inputs In Sustainable Agriculture (LEISA). Conference: Academic PG credit seminar. DOI:10.13140/RG.2.2.10373.58081.

[11] Prihastuti, 2016. The strategy of developing sweet potato cultivation in tidal land. El-Hayah. 6. 01. 1-6. DOI: 10.18860/elha.v6i1.3980.

[12] Setiyo, Y.H., B. Gunam, I. Gunadnya, I.D.P. Yulianti, N.I. Triani, 2021. Application of the LEISA system to improve soil properties and increase potato productivity. International Journal of Pharmaceutical Research, 13: 3014-3021. DOI: https://doi.org/10.31838/ijpr/2021.13.02.391.

[13] Islam, M.F., G. Akter, A. Hossain, M.N. Dilip, 2017. Effect of Organic, Inorganic Fertilizers and Plant Spacing on the Growth and Yield of Cabbage. Agriculture. 7(31). DOI:10.3390/agriculture7040031.

[14] Sutrisno, S. \& E. Yusnawan, 2018. Effect of manure and inorganic fertilizers on vegetative, generative characteristics, nutrient, and secondary metabolite con-tents of mungbean. Biosaintifika: Journal of Biology \& Biology Education, 10: 56-65.

[15] Anggraheni, Y.G.D., F. Nuro, and Y.B. Paradisa, 2019. Effect of organic fertilizer on growth and yield of chili pepper. The $3^{\text {rd }}$ Satreps Conference 2018. The $376^{\text {th }}$ RISH Symposium and The $9^{\text {th }}$ Flagship Symposium of Tropical Plant Biomass. Vol 1, Mei 2019. Bogor November 22 ${ }^{\text {nd }}, 2018$. 
[16] Sutariati, G.A.K., N.M. Rahni, A. Madiki, L. Mudi, I.M. Guyasa and Zahrima, 2020. Characterization of endophytic-rhizobacteria from areca nut rhizosphere to dissolve phosphates, nitrogen fixation of IAA hormone synthesis. Pak. J. Biol. Sci., 23: 240-247.

[17] Li, Z., C. Song and Y. Yi, 2020. Characterization of plant growth-promoting rhizobacteria from perennial ryegrass and genome mining of novel antimicrobial gene clusters. BMC Genomics, 21(2020) 157.

[18] Mei, C., R.L. Chretien, B.S. Amaradasa, Y. He, A. Turner and S. Lowman, 2021. Characterization of phosphate solubilizing bacterial endophytes and plant growth promotion in vitro and in greenhouse. Microorganisms, 9(2021) 1935. https://doi.org/10.3390/microorganisms9091935.

[19] Zafar, S., A. Bano and T.U.1. Hassan, Evaluation of indole-3-acetic acid deficient mutants of Pseudomonas moraviensis and its role in mitigation of salt stress in Cicer arietinum L. Pak. J. Bot., 54: 1-10. DOI: http://dx.doi.org/10.30848/PJB2022-2(6).

[20] Sutariati, G.A.K., N.M. Rahni, L. Mudi, R.R. Maharani and G.N.A. Wibawa, 2021. The effectiveness of endo-rhizo bacterial isolated from areca nut rizosphere (Areca cathecu L.) in breaking dormancy and improvement of seed vigor. IOP Conference Series: Earth and Environmental Science, 807(4): 042039. doi:10.1088/1755-1315/807/4/042039.

[21] Timmusk, S., 2003. Mechanism of actions of the the plant-growth-promoting rhizo bacterium Paenibacillus polymixa [Dissertation]. Uppsala, Sweden: Departement of Cell and Molecular Biology, Uppsala University.

[22] Sutariati, G.A.K., Widodo, Sudarsono dan S. Ilyas, 2006. Pengaruh perlakuan plant growth promoting rhizobacteria terhadap pertumbuhan bibit tanaman padi. Buletin Agronomi, 34: 46-54.

[23] Sutariati, G.A.K., Widodo, Sudarsono, dan S. Ilyas, 2006. Efektivitas agens biokontrol untuk meningkatkan pertumbuhan dan hasil cabai serta mengendalikan penyakit antraknosa di rumah kaca. Agriplus, 16: 103-111.

[24] Sutariati, G.A.K. dan L.O. Safuan, 2012. Perlakuan benih dengan rizobakteri meningkatkan mutu benih dan hasil cabai (Capsicum annuum L.). J. Agron. Indonesia 40: 125-131.

[25] Sutariati, G.A.K. dan A. Wahab, 2011. Karakter fisiologi dan kemangkusan rizobakteri indigenos sulawesi tenggara sebagai pemacu pertumbuhan tanaman cabai. J. Hort. 22: 57-64.

[26] Ilyas, S., G.A.K. Sutariati, F.C. Suwarno and Sudarsono, 2002. Matriconditioning improved quality and protein level of medium vigor hot pepper seed. Seed Technol., 24: 65-75.

[27] Silva, H.S.A., R.S.R. Romeiro, D. Macagnan, B.A.H. Vieira, M.C.B. Pereira and A. Mounteer, 2004. Rhizobacterial induction of systemic resistance in tomato plants: non-specific protection and increase in enzyme activities. Biol Control, 29:288-295.

[28] Yan, Z., C.M. Ryu, J. McInroy, M.S. Reddy, F. Woods, M. Wilson and J.W. Koepper. 2004. Induction of systemic resistance against tomato late blight by plant growth promoting rhizobacteria (PGPR). http://www.ag.auburn.edu/argentina/pdfmanuscripts/yan2.pdf.

[29] Zhang, Y., 2004. Biocontrol of sclerotia stem root of canola by bacterial antagonist and study of biocntrol mechanism involved. Thesis. Departemen of Plant Science, University of Manitoba. Canada.

[30] Wahid A, A. Noreen, M.A. Shahzad, Basra, S. Gelani and M. Farooq, 2008. Priming-induced metabolic changes in sunflower (Helianthus aпnииs) achenes improve germination and seedling growth. Botanical Studies, 49: 343-350.

[31] Desai BB, Kotecha PM, Salunkhe DK. 1997. Seeds handbook, biology, production, processing and storage. Marcel Dekker Inc. USA.

[32] Moradi A. and Younesi O. 2009. Effects of osmo- and hydro-priming on seed parameters of grain sorghum (Sorghum Bicolor L.). Australian Journal Of Basic And Applied Sciences, 3: 1696-1700

[33] Sutariati, G.A.K. dan A. Wahab. 2010. Isolasi dan uji kemampuan rizobakteri indigenous sebagai agens pengendali hayati penyakit pada tanaman cabai. Jurnal Hortikultura, 20: 86-95.

[34] Chaves, E.I.D., V.F. Guimarães, E.C.G. Vendruscolo, M. Fonseca dos Santos, F. Freitas de Oliveira, J.A. Cordeiro de Abreu, M.P. Camargo, V.S. Schneider, E. Maltempi de Souza, L.M. Cruz and E. Soares de Vasconcelos. 2019. Interactions between endophytic bacteria and their effects on poaceae growth performance in different inoculation and fertilization conditions. AJCS, 13: 69-79.

[35] Liu, Z., X. Zhang and L. Li, 2021. Isolation and characterization of three plant growth-promoting rhizobacteria for growth enhancement of rice seedling. J Plant Growth Regul. (2021).

[36] Ashrafuzzaman, M., F.A. Hossen, M.R. Ismail, Md.A. Hoque, M.Z. Islam, S.M. Shahidullah and S. Meon. 2009. Efficiency of plant growth-promoting rhizobacteria (PGPR) for the enhancement of rice growth. African Journal of Biotechnology., 8:1247-1252. 
[37] ElSorra, E.I., J. I Domingo, T. Manuel and B. Rainer, 2007. Tryptophan-dependent productionof indole-3acetic acid (IAA) affects level of plant growth promotion by Bacillus amyloliquefaciens FZB42. The American Phytopathological Society., MPMI 20: 619-626.

[38] Park, K.H., C.Y. Lee and H.J. Son, 2009. Mechanism of insoluble phosphate solubilization by Pseudomonas fluorescens RAF15 isolated from gingseng rhizophre and its plant growth-promoting activities. Lett. Appl. Microbiol, 49: 222-8.

[39] Mehrab, Y.H., A. Rahmani, G. Noormohammadi and A. Ayneband. 2010. Plant growth promoting rhizobacteria increase growth, yield and nitrogen fixation in Phaseolus vulgaris. Journal of Plant Nutrition, 33: $1733-1743$.

[40] Sutariati, G.A.K dan A. Wahab, 2012. Kararkter fisiologis dan kemangkusan rizobakteri indigenus sebagai pemacu pertumbuhan Tanaman Cabai. J. Hotikultura, 22: 57-64.

[41] Datta, M., R. Palit, C. Sengupta, M.K. Pandit and S. Banerjee, 2011. Plant growth promoting rhizobacteria enhance growth and yield of chilli (Capsicum annuum L.) under field conditions. Australian Journal of Crop Sciences 5: 531-36.

[42] Vacheron, J., G. Desbrosses, M.L. Bouffaud, B. Touraine, Y. Moënne-Loccoz, D. Muller, L. Legendre, F. Wisniewski-Dyé and C. Prigent-Combaret, 2013. Plant growth-promoting rhizobacteria and root system functioning. Front Plant Sci. 4: 1-19.

[43] Elango. R, R. Parthasarathi and S. Megala, 2013. Field level studies on the association of plant growth promoting rhizobacteria (PGPR) in Gloriosa Superba L. rhizosphere. Indian Streams Research Journal, 3:16 .

[44] Ilyas, S., K.V. Asie and G.A.K. Sutariati, 2014. Biomatriconditioning or biopriming with biofungicides or biological agents applied on hot pepper (Capsicum annuиm L.) seeds reduced seedborne Colletotrichum capsici and increased seed quality and yield ISHS Acta Hortic. 1105: 89-96.

[45] Ambawade, S. and G.R. Pathade, 2015. Production of gibberellic acid by Bacillus siamensis BE 76 isolated from banana plant (Musa spp.). International Journal of Science and Research, 4: 2319-7064.

[46] Sutariati, G.A.K., K. Jusoff, I.G.R. Sadimantara, A. Khaeruni, Muhidin and Meisanti, 2013. Effectiveness of bio-invigoration technologies on seed viability and vigor of cocoa (Theobroma cacao L.). World Applied Sciences Journal (Natural Resources Research and Development in Sulawesi Indonesia), 26: 31-36.

[47] Mujahid, T.Y., S.A. Subhan, A. Wahab, J. Masnoon, N. Ahmed and T. Abbas, 2015 Effects of different physical and chemical parameters on phosphate solubilization activity of plant growth promoting bacteria isolated from indigenous soil Journal of Pharmacy and Nutrition Sciences, 5: 64-70.

[48] Zahid, M., M.K. Abbasi, S. Hameed and N. Rahim, 2015. Isolation and identification of indigenous plant growth promoting rhizobacteria from Himalayan region of Kashmir and their effect on improving growth and nutrient contents of maize (Zea mays L.). Front Microbiol. 6: 1-10.

[49] Widayanti, T., 2007. Isolasi dan karakterisasi Bacillus sp. indigenus penghasil asam indol asetat asal tanah rizosfer. Skripsi. Depatermen Biologi, Fakultas Metematika dan Ilmu Pengetahuan Alam. Institut Pertanian Bogor.

[50] Sutariati, G.A.K., 2006. Perlakuan benih dengan agens biokontrol untuk pengendalian penyakit antraknosa, peningkatan hasil dan mutu benih padi. Disertasi. Program Pascasarjana Institut Pertanian Bogor.

[51] Mishra, R.K., O. Prakash, M. Alam and A. Dikshit, 2010. Influence of plant growth promoting rhizobacteria (PGPR) on the productivity of Pelargonium graveolens L. Herit. Recent Research in Science and Technology, 2: 53-57.

[52] Erturk, Y., S. Ercisli., A. Haznedar dan R. Cakmakci, 2010. Effects of plant growth promoting rhizobacteria (PGPR) on rooting and root growth of kiwifruit (Actinidia deliciosa) stem cuttings. Biol. Res., 43: 91-98.

[53] Chauhan, H., D. Bagyaraj, G. Selvakumar and S. Sundaram, 2015. Novel plant growth promoting rhizobacteria-prospects and potential. Appl. Soil Ecol. 95: 38-53. doi: 10.1016/j.apsoil.2015.05.011.

[54] Sutariati, G.A.K., N.M. Rahni, A. Madiki, and I.M. Guyasa. 2020. Characterization of Endophyticrhizobacteria from areca nut rhizosphere to dissolve phosphates, nitrogen fixation of IAA hormone synthesis. Pakistan Journal Of Biological Sciences: PJBS, 23: 240-247.

[55] Bhutani, N., R. Maheshwari, N. Monika and S.D. Pooja, 2018. Optimization of IAA production by endophytic Bacillus spp. from Vigna radiata for their potential use as plant growth promoters. Israel Journal of Plant Sciences, 65. 10.1163/22238980-00001025.

[56] Andriūnaitè, E., I. Tamošiūnè, M. Aleksandravičiūtè, D. Gelvonauskienė, J. Vinskienè, R. Rugienius and D. Baniulis, 2021. Stimulation of Nicotiana tabacum L. in vitro shoot growth by endophytic Bacillus cereus group bacteria. Microorganisms, 9: 1893. https://doi.org/10.3390/microorganisms9091893. 